\title{
The Relationship between Corporate Profitability and Macroeconomic Indicators: \\ Evidence from 500 Largest Industrial Organizations in Turkey
}

\author{
Ferhan Emir Tuncay ${ }^{1}$, Hulya Cengiz ${ }^{2}$ \\ ${ }^{1}$ Faculty of Applied Sciences, Kadir Has University, Istanbul, Turkey \\ ${ }^{2}$ Graduate School of Social Sciences, Yildiz Technical University, Istanbul, Turkey \\ Correspondence: Hulya Cengiz, Graduate School of Social Sciences, Yildiz Technical University, Istanbul, \\ Turkey.
}

Received: June 20, 2017

doi:10.5539/ibr.v10n9p87

\author{
Accepted: July 27, 2017 \\ Online Published: August 14, 2017 \\ URL: https://doi.org/10.5539/ibr.v10n9p87
}

\begin{abstract}
The purpose of this study is to examine the impact of chosen macroeconomic indicators on industrial corporate performance. In the analysis, economic profitability ratios of Turkey's top 500 industrial firms, which represent the Turkish economy, have been used to estimate performance. In order to determine the effects of macroeconomic indicators, panel data with a non-linear instrumental variables estimator, Arellano Bond generalized methodology of moments (GMM) was used between the period of 2002 and 2012. As a result of the analysis, gross domestic product, inflation rate, the rate of domestic debt interest payments to the net new borrowing and the rate of domestic debt interest payments to total income tax have a direct relationship with corporate performance. On the other hand, exchange rate, interest rate and the rate of short term foreign debts to central bank international reserves have an inverse relationship.
\end{abstract}

Keywords: corporate profitability, macroeconomic indicators, financial structure, panel data, GMM

\section{Introduction}

The performance of the economy is measured by macroeconomic indicators that are affected by various unexpected developments such as, external deficits, the growth rate of the economy, foreign trade rates, domestic interest rates, deviations in the exchange rate, inflation rate, national and international debts and an increase of oil prices. Macroeconomic indicators may affect the microeconomic indicators such as exchange risk, credit risk, profitability rates, financial structure rates, stock prices and returns. In previous studies, the relationship between microeconomic and macroeconomic indicators was analysed for different periods according to development level of the countries. These studies mainly analysed the effects of macroeconomic indicators on stock prices, stock returns, the stock index in literature. Therefore, this study is focused on the relationship between macroeconomic indicators and the profitability of companies in Turkey. In this sense, the relationship between macroeconomic indicators and profitability of the top 500 Largest Industrial Organizations in Turkey was investigated in this study. To evaluate profitability, economic profitability is considered which in turn is the ratio of the net value added created by companies to their total assets. It is also known as asset productivity.

The top 500 Largest Industrial Organizations play a major role in Turkey. Their performance determines the performance of the Turkish economy. In 2014, the total exports of Turkey were $\$ 157.6$ billion even as the top 500 largest industrial organizations of Turkey exported $\$ 61.3$ billion. The rate of created value added in industry by top 500 largest industrial organizations was $22.6 \%$ in 2013; $21.3 \%$ in 2014 with basic prices (The Top 500 Largest Industrial Organizations of Turkey 2014, 2015). The rate of created gross value added with production cost and GDP in industry by top 500 largest industrial organizations was 8.4\% in 2013; 7.5\% in 2014 (The Top 500 Largest Industrial Organizations of Turkey 2014, 2015). So these companies represent the Turkish Economy and are essential for an economic analysis of Turkey.

The rest of the study is classified as follows. Section 2 is a brief review of recent studies that are related to this research. Dependent and independent indicators are defined, data preparation is explained in section 3; methodology is discussed in section 4; empirical findings are presented in section 5 and section 6 concludes the paper. 


\section{Literature}

In pre vious empirical studies, the effects of macroeconomic indicators were mainly analysed for stock prices, stock returns, stock index, and profitability of companies. Macroeconomic indicators were evaluated by exchange rates, interest rate, inflation rate, money supply, cacao-oil-gold prices, economic activity level, default premium, maturity premium, slope of the yield curve, gross domestic product, unemployment, foreign direct investment, state debt, harmonized consumer price index, industrial production index, volume of trade, bank loans, in these studies. These empirical studies can be grouped according to the aims of analysis.

\subsection{The Relationship between Stock Price and Macroeconomic Indicators}

Some studies found positive or negative correlations for specific periods. It was found a negative correlation between exchange rates and stock prices the period from 1986 to 1994 for Mexican Stock Exchange (Bailey \& Chung, 1995), positive correlation in the period 1966-1970 and 1973-1977 for the U.S. companies (Bartov, Bodnar, \& Kaul, 1995). The relationship between stock prices and macroeconomic indicators was not limited to just exchange rate. It was observed for deposit bank interest rate, inflation rate, money supply, cacao-oil-gold prices. According to these studies, an increase in deposit bank interest rates and inflation had negative effects on stock prices in the 1991-2005 period (Kyereboah-Coleman \& Agyire-Tettey, 2008), an increase in cacao prices and interest rates increased volatility of the stock prices but the volatility in gold, oil prices and money supply decreases volatility of stock prices for period between 1991-2007 on Ghana Stock Index (Adjasi, 2009). In Vietnam, an increase in interest rates decreased stock prices for the period between 2001-2008 (Hussainey \& Khanh Ngoc, 2009). Another extended study was carried out for fifteen developed and de veloping countries ${ }^{1}$ from 1988 to 2003 and a negative correlation was observed between interest rates and stock prices (Alam \& Uddin, 2009). According to Al Shakar's study the increases in real economic activity, money supply and interest rate raised stock prices; the increase in inflation decreased stock prices from 1980 to 2003 in Jordanian stock market (Al-Sharkas, 2004). The effect of macroeconomic indicators on stock prices in Turkey was studied from the period 1986 to 1998 (Durukan, 1999). The interest rate affected the stock prices negatively but inflation, interest rate, economic activity level, money supply and exchange rate did not affect stock prices. On the contrary, when the effects of the change in inflation rate on stock prices was examined, no statistically significant relationship has been determined (Karamustafa \& Karakaya, 2004). Therefore, the results of the research mentioned above differ according to selected periods and the level of development of the countries.

\subsection{The Relationship between Stock Return and Macroeconomic Indicators}

A positive correlation was found between exchange rates and stock returns for multinational companies in the U.S. (Jorion, 1990), in South Africa and Egypt. In turn, a negative correlation in was found in Tunisia, Ghana, Kenya, Mauritius and Nigeria (Adjasi, Biekpe, \& Osei, 2011). However it was determined that the increase in the inflation rate had negative effects on stock returns in the U.S. companies (Flannery \& Protopapadakis, 2002; Sharpe, 1999). Also, Bartov and Bodnar (Bartov \& Bodnar, 1994) observed a positive correlation between lagged changes in the dollar and current abnormal returns of U.S. companies. Conversely, it was found that macroeconomic variables such as growth rate of monthly industrial production, default premium ${ }^{2}$, real interest rate, maturity premium ${ }^{3}$, slope of the yield curve ${ }^{4}$ and change in monthly expected inflation had no effect on stock returns in the Japanese and U.K. markets over the period of 1968 to 1993 (Chan, Karceski, \& Lakonishok, 1998). Turkish stock returns were compared to German stock returns in terms of effects of macroeconomic indicators (Altay, 2003). Accordingly, the unexpected interest rate factor and the unexpected inflation factor affected asset returns of the German stock market, but it did not offer any evidence for the Turkish stock market.

\subsection{The Relationship between Stock Index and Macroeconomic Indicators}

The relationship between interest rates and the stock index was carried out for the period from 1989 to 2002 in the United States (Bernanke \& Kuttner, 2005). Also, various macroeconomic indicators ${ }^{5}$ were analysed for the

\footnotetext{
${ }^{1}$ Australia, Bangladesh, Canada, Chile, Colombia, Germany, Italy, Jamaica, Japan, Malaysia, Mexico, Philippine, S. Africa, Spain, and Venezuela

${ }^{2}$ Measured as the difference between the monthly return on a high yield bond index and the return on long term government bonds

${ }^{3}$ The difference between the return on long term government bonds and the one month Treasury bill return

${ }^{4}$ The difference between the yield on long term government bonds and the yield on Treasury bills

${ }^{5}$ Gross domestic product, unemployment, foreign direct investment, state debt, harmonized consumer price index, money supply, export, import, trade balance and short-term interest rates.
} 
period between 2000 and 2008 in Stock market index of Lithuania Lat via Estonia (Pilinkus, 2010). Oskenbayev et. al. (Oskenbayev, Yilmaz, \& Chagirov, 2011) determined the short and long term relationship between the macroeconomic variables ${ }^{6}$ and the Kazakhstan stock index for the period of 2001-2009. Similarly in another study, it was determined the short and long term effects of macroeconomic variables ${ }^{7}$ on the stock index are in compliance with a theory on Sri Lanka Stock Exchange for the period 1985-2004 (Wickremasinghe, 2011). There was a negative relationship between ISE-100 index and exchange rate, interest rate, oil price and industrial production index but a positive relationship between index and money supply and no relationship between the index and inflation rate and gold price for the period 2003-2010 (Buyuksalvarci, 2010).

\subsection{The Relationship between Profitability and Macroeconomic Indicators}

The relation between exchange rate and profitability was determined for the years of 1970's (Dumas, 1978; Shapiro, 1975). Baum et al. described the components which affect the profitability as permanent and transitory components. They determined a negative correlation between permanent components and exchange rate; but a positive correlation. between the transitory component and exchange rate (Baum, Caglayan, \& Barkoulas, 2001). Furthermore, profitability of the banks, evaluated as return on average assets, was affected by macroeconomic conditions in the 15 EU countries ${ }^{8}$ over the period 1995-2001 (Pasiouras \& Kosmidou, 2007). Changes of unexpected exchange rate affected the profitability of American multinational companies in the period 1988-1993 (Gao, 2000). The permanent profitability was analysed by using 172 companies among 500 largest companies listed in Istanbul Chamber of Industry for the period 1985-1998 and it was found that the characteristics of the companies, rather than those of the industry, indicate the permanent profitability (Yurtoglu, 2004). Profitability of companies was very sensitive to Consumer Price Index and Producer Price Index in sectors of beverages and food in Borsa İstanbul from the period 1998-2007 (Aydeniz, 2009). On the other hand, no significant relationship was found between macroeconomic variables (inflation and growth rates) and profitability of companies in the Tunisian banking industry for the 1980-2000 period (Naceur, 2003).

Profitability was evaluated by using macroeconomic indicators that were mentioned in the studies above. In other studies, various other indicators were observed. Sector impacts, sector concentration, product differentiation and stage of life cycle (Caloghirou, Protogerou, Spanos, \& Papagiannakis, 2004); ownership structures, size, degrees of diversification and geographical location (Guerrini, Romano, \& Campedelli, 2011); country effects (Goldszmidt, Brito, \& de Vasconcelos, 2011); differences of government, trade policies, technology levels, internal competition and culture (Ketelhöhn \& Quintanilla, 2012); firm strategy and the industry structure (Karabag \& Berggren, 2014); market power and more efficient operation (Canarella, Miller, \& Nourayi, 2013); lagged profitability, growth, productivity, firm age and industry affiliation (Yazdanfar, 2013) were used as indicators to explain the relationship with corporate profitability.

\section{Data}

Economic profitability, which is the rate of the net value added created by companies to their total assets and which is also known as asset productivity, was used to evaluate the profitability in this study. Profitability ratios of the 500 largest industrial organizations in Turkey, which represent the Turkish economy, have been used in the analysis. These industrial organizations are announced in annual reports by Istanbul Chamber of Industry. The 500 largest industrial enterprises are listed based on sales figures announced every year. The selection and ranking of the 500 largest industrial organizations are based on their annual sales as announced and published by the Istanbul Chamber of Commerce. They were classified according to the sectors in which they perform. While classifying the sectors, the United Nations International Standard Industrial Classification of All-Economic Activities-ISIC Rev. 2-("United Nations Statistics Division," 2015) has been considered. Sectoral classification is demonstrated in Appendix 1. The sectoral profitability ratios were compiled from annual reports regularly announced to the public by Istanbul Chamber of Industry. Only the ratios of the period of 2002-2012 are solely in the analysis. As the encoding of the industry data for the period 2013-2014 changed according to the Statistical Classification of Economic Activities in the European Community-NACE Rev.2-(Eurostat, 2008), the data for the above-mentioned period was excluded from the study.

\footnotetext{
${ }^{6}$ Index of industrial production, inflation rate, exchange rate, long and short-term bank loans, oil price volatility and volume of trade.

${ }^{7}$ The amount of Sri Lankan rupees per unit of USD, three-month fixed deposit rate, Colombo consumers' price index, US stock market index, narrow M1, and the GDP of Sri Lanka on a monthly basis.

${ }^{8}$ Austria, Belgium, Denmark, Finland, France, Germany, Greece, Ireland, Italy, Luxembourg, The Netherlands, Portugal, Spain, Sweden, UK.
} 
To estimate the effects of macroeconomic indicators on profitability, exchange rate, interest rate, inflation, gross domestic product (GDP), the rate of short term foreign debts to central bank international reserves, the rate of domestic debt interest payments to the net new borrowing and, the rate of domestic debt interest payments to total income tax were used. The definitions of these macroeconomic indicators that affect the economic profitability are shown in Table 1.

Table 1. Macroeconomic Indicators in the Analysis

\begin{tabular}{|c|c|c|}
\hline \multicolumn{2}{|c|}{ Independent Variables } & \multirow{2}{*}{$\begin{array}{l}\text { Definition } \\
\text { In this study the exchange rate was based on the U.S. dollar as announced by } \\
\text { the Central Bank of Turkey at the end of the year. }\end{array}$} \\
\hline EX & Exchange rate & \\
\hline INT & Interest rate & $\begin{array}{l}\text { Annual interest rates, announced by the Central Bank of Turkey, are used in } \\
\text { the study. }\end{array}$ \\
\hline INF & Inflation rate & Domestic producer price index is used as the inflation rate. \\
\hline GDP & Gross Domestic Product & Market value of goods and services produced by labor and property in Turkey. \\
\hline FD & $\begin{array}{l}\text { Rate of short term } \\
\text { foreign debts to central } \\
\text { bank international } \\
\text { reserves }(\%)\end{array}$ & $\begin{array}{l}\text { Short term foreign debts / Central bank international reserves. An increase in } \\
\text { this rate indicates an increasing amount of debt for the economy. This may } \\
\text { result in a liquidity crisis. }\end{array}$ \\
\hline NB & $\begin{array}{l}\text { Rate of domestic debt } \\
\text { interest payments to the } \\
\text { net new borrowing }\end{array}$ & $\begin{array}{l}\text { Domestic debt interest payments over the net new borrowing. } \\
\text { This rate shows how much of the borrowing amount is used for debt interest } \\
\text { payments. }\end{array}$ \\
\hline IT & $\begin{array}{l}\text { Rate of domestic debt } \\
\text { interest payments to } \\
\text { total income tax }\end{array}$ & $\begin{array}{l}\text { Domestic debt interest payments overotal income tax } \\
\text { This rate shows how much of the tax income is used for debt interest } \\
\text { payments. }\end{array}$ \\
\hline
\end{tabular}

\section{Method and Hypotheses}

The variables are formed based on repeated observations on the same cross section of the sectors for the period of 2002-2012. Panel data was used to estimate the effects of macroeconomic indicators that are dynamic in models containing lagged values of profitability. Known as an Arellano Bond generalized method of moments estimator, a non-linear instrumental variables estimator, it optimally exploits all the linear moment restrictions that follow from the assumption of no serial correlation in the errors, in an equation which contains individual effects, lagged dependent variables and no strictly exogenous variables (Equation 1) (Arellano \& Bond, 1991). Namely, GMM estimators that used all the available lags at each period as instruments for the equations in first differences were proposed by Holtz-Eakin, Newey and Rosen and, Arellano-Bond (Equation 2) (Arellano, 2003). Arellano and Bond proposed one-step and two-step estimators. In this study, we use the one-step GMM estimator. The main hypothesis and the regression model is shown below.

$\mathrm{H}_{1}$ : Firm profitability is affected by macroeconomic indicators and lagged values of profitability. $(\sigma \neq 0)$ $(\mathrm{B} \neq 0)$

$$
Y_{i t}=\sigma Y_{i t-1}+\beta_{1} X_{1 i t}+\beta_{2} X_{2 i t}+\beta_{3} X_{3 i t}+\beta_{4} X_{4 i t}+\beta_{5} X_{5 i t}+\beta_{6} X_{6 i t}+\beta_{7} X_{7 i t}+\alpha_{i}+u_{i t}
$$

$\mathrm{X}_{1,2, \ldots 7}=\mathrm{EX}, \mathrm{INT}, \mathrm{INF}, \mathrm{GDP}, \mathrm{STFD} / \mathrm{CBIR}, \mathrm{DDIP} / \mathrm{TNNB}, \mathrm{DDIP} / \mathrm{TIT}$.

$\mathrm{t}=1,2, \ldots .11$ and

$\mathrm{i}=1,2, \ldots, 8$.

The first difference of this equation can be shown as follows:

$$
\Delta Y_{i t}=Y_{i t}-Y_{i t-1}=\Delta \sigma Y_{i t-1}+\Delta \beta_{1} X_{1 i t}+\Delta \beta_{2} X_{2 i t}+\Delta \beta_{3} X_{3 i t}+\Delta \beta_{4} X_{4 i t}+\Delta \beta_{5} X_{5 i t}+\Delta \beta_{6} X_{6 i t}+\Delta \beta_{7} X_{7 i t}+\Delta u_{i t}
$$

Arellano Bond proposed a test for serial correlation in first differenced residuals. This test calculates the firstand second-order autocorrelation in the first-differenced errors. If the errors are serially independent, those in first-differences will exhibit first- but not second-order serial correlation (Arellano, 2003). Because the first difference of independently and identically distributed idiosyncratic errors will be serially correlated, rejecting the null hypothesis of no serial correlation in the first-differenced errors at order one does not imply that the 
model is misspecified. Rejecting the null hypothesis at higher orders implies that the moment conditions are not valid ("Arellano-Bond Linear Dynamic Panel-Data Estimation," 2015)

The test of the validity of instrumental variables is tested with the Sargan test of over-identifying restrictions. All variables other than the lagged dependent variables are assumed to be strictly exogenous, although none of the over-identifying restrictions that follow from this assumption are exploited (Arellano \& Bond, 1991).

\section{Empirical Findings}

The lagged dependent variable is statistically significant in explaining economic profitability and it has a positive sign as expected. Similarly, all independent variables are statistically significant for economic profitability. The rate of domestic debt interest payments to the net new borrowing, the rate of domestic debt interest payments to total income tax, GDP, inflation rate affect positively; the rate of short term foreign debts to central bank international reserves, exchange rate, interest rate affect negatively. Wald test was used to test overall significance of the statistical model. The model is statistically significant $(\mathrm{p}=0.0000<0.05)($ Table 2$)$.

Table 2. Arellano Bond GMM Estimation, Serial Correlation and Sargan Test Results

\begin{tabular}{lllll}
\hline & Coefficient & Standard Error & Z & P>IzI \\
\hline Economic Profitability L1 & 0.308 & 0.109 & 2.84 & 0.005 \\
EX & -3.553 & 0.754 & -4.71 & 0.000 \\
INT & -0.513 & 0.139 & -3.7 & 0.000 \\
INF & 0.222 & 0.093 & 2.39 & 0.017 \\
GDP & 0.316 & 0.113 & 2.79 & 0.005 \\
FD & -0.106 & 0.042 & -2.50 & 0.012 \\
NB & 0.106 & 0.037 & 2.83 & 0.005 \\
IT & 0.193 & 0.069 & 2.79 & 0.005 \\
\hline Wald-test & $\chi^{2}(8)=41.48$ & & & \\
AR(1) & p-value =0.0000 & & & \\
AR(2) & $\mathrm{z}=-6.2659$ & & & \\
\hline
\end{tabular}

The first- and second-order autocorrelations are tested using Arellano Bond serial correlation test. So, as expected, the output (Table 2) presents strong evidence $(\mathrm{p}=0.0000<0.05)$ against the null hypothesis of zero autocorrelation in the first-differenced errors at order 1 (AR1). However, the output above presents no significant evidence $(\mathrm{p}=0.4505>0.05)$ of serial correlation in the first differenced errors at order 2 (AR2) $\left[\mathrm{E}\left[\Delta \mathrm{u}_{\mathrm{it}} \Delta \mathrm{u}_{\mathrm{it}-2}\right]=0\right]$ as expected.

The validity of instrumental variables was tested with the Sargan test of over identifying restriction. The output presents evidence that the null hypothesis should not be rejected, therefore, over-identifying restrictions are valid as follows.

$$
\chi^{2}(44)=49.22645 \text { Prob }>\chi^{2}=0.2719
$$

The number of instruments in the model $(\mathrm{p})=52$

The number of parameters $(\mathrm{k})=8$

\section{Conclusion}

Macroeconomic indicators which were defined as independent variables affect the profitability of the top 500 largest industrial organizations. The performance of these organizations plays a major role in the Turkish economy. The performance evaluated economic profitability that is the rate of the net value added created by firms to its total assets. It is also known as asset productivity. The sectoral profitability ratios were compiled from annual reports each year regularly declared to the public according to sectors for the period of 2002-2012.

Arellano Bond generalized method of moments estimator was used to estimate the effects of macroeconomic indicators that are dynamic in models containing lagged values of profitability. Macroeconomic indicators are exchange rate, interest rate, inflation rate, gross domestic product, the rate of short term foreign debts to Central Bank international reserves, the rate of domestic debt interest payments to the net new borrowing and, rate of domestic debt interest payments to total income tax in the analysis.

Lagged values of profitability, the rate of domestic debt interest payments to the net new borrowing, the rate of domestic debt interest payments to total income tax, GDP, inflation rate affect profitability positively; the rate of short term foreign debts to central bank international reserves, exchange rate, interest rate affect negatively.

The rate of short term foreign debts to central bank international reserves shows the share of the short term 
foreign debt payments with respect to the reserves of the Central Bank. The increase in this rate can be interpreted as an increase in the debt of the economy and a liquidity problem. There is a negative relationship between this rate and profitability. The increase in this rate leads to the economic crisis of liquidity. While foreign debt payments are increasing, international reserves are expected to decline. By increasing the Central Bank International Reserves through the increase in foreign exchange inflows to the country (e.g. increase in exports and decrease in imports), this rate can be lowered. For this reason, it is expected that there is a negative relationship between profitability and this rate.

The rate of domestic debt interest payments to the net new borrowing shows how much of the borrowing amount is used for debt interest payments. The rate of domestic debt interest payments to the net new borrowing represents the share of the government's domestic debt payments in the new borrowing. The high rate indicates that the government hasn't paid its debts with the new debt. This low rate indicates that the debt is paid by borrowing new debt. The government borrows to invest in or to pay interest. In the study, there is a positive relationship between profitability and this rate. Because government uses tax revenues, other revenues or borrows to make domestic debt interest payments on Treasury bonds and bills. Accordingly, if tax revenues are increased instead of borrowing, this rate will increase. An increase in tax revenues can be related to profitability. Therefore, when the tax revenues increase, the government will charge more taxes to pay the domestic debt interest payments. So, tax incomes should be considered when assessing this rate.

The rate of domestic debt interest payments to total income tax shows how much of the tax income is used for debt interest payments. There is a positive relationship between this rate and profitability. If the government pays interest on domestic debt from collecting taxes and uses the savings rather than tax only in the payment, it can be said that there is a positive relationship between this rate and profitability.

It was stated that one of the main reasons for the positive relationship between the rate of domestic debt interest payments to the net new borrowing, the rate of domestic debt interest payments to total income tax, GDP, inflation rate, and profitability could be increase in tax revenues due to the increase in the profitability and used for domestic debt interest payments. The positive relationship between the rate of domestic debt interest payments to total income tax and profitability confirms this expression. The tax burden will increase as the incomes of the enterprises increase. In addition to real investment, businesses can invest in bonds and treasury bills. Therefore, there is a negative relationship between domestic debt interest payments and profitability due to the increase in tax revenues.

Gross domestic product is the currency value of goods and services produced in a country in a given period. Therefore, as the goods and services produced in the country increase, the profitability is expected to increase.

There is a negative relationship between the interest rate and the inflation rate. The increase in the general level of prices is inflation. Inflation occurs if the demand for goods and services produced in a country exceeds production. In addition, the increase in the payments made to the production factors and the payments made to the inputs used in the production are reflected in the prices, which causes the inflation. Therefore, it is expected that inflation will increase as the production amount will increase as the profitability of the enterprises increases. On the other hand, if interest rates increase, this investment will be directed and will have an effect on reducing inflation.

It is seen that the increase in the exchange rate will decrease the profitability because the enterprises using input from abroad will increase their costs. However, when the number of exporting enterprises increases, the cost increase for input will create a greater added value in the sale of goods, so this time will have a po sitive effect. Since the majority of manufacturing enterprises in Turkey use imported inputs, the increase in the exchange rate also reflects the costs in the short term. However, since sales prices can't be increased in the short term, this situation will result in a decrease in the profitability of the enterprises.

When all these variables are taken into consideration, there is an interaction between macroeconomic variables and the profitability of the enterprises. Moreover, this increase will affect macroeconomic variables positively as well as the correct orientation of the value added resulting from increased profitability of the enterprises.

\section{References}

Adjasi, C. K. (2009). Macroeconomic Uncertainty and Conditional Stock-Price Volatility in Frontier African markets: Evidence from Ghana. The Journal of Risk Finance, 10(4), 333-349. https://doi.org/10.1108/15265940910980641

Adjasi, C. K., Biekpe, N. B., \& Osei, K. A. (2011). Stock Prices and Exchange Rate Dynamics in Selected African Countries: A Bivariate Analysis. African Journal of Economic and Management Studies, 2(2), 


\section{3-164. https://doi.org/10.1108/20400701111165623}

Al-Sharkas, A. (2004). The Dynamic Relationship between Macroeconomic Factors and the Jordanian Stock Market. International Journal of Applied Econometrics and Quantitative Studies, $1,1$.

Alam, M. M., \& Uddin, M. G. S. (2009). Relationship between Interest Rate and Stock Price: Empirical Evidence from Developed and Developing Countries. International journal of business and management, 4(3), 43. https://doi.org/10.5539/ijbm.v4n3p43

Altay, E. (2003). The Effect of Macroeconomic Factors on Asset Returns: A Comparative Analysis of the German and the Turkish Stock Markets in an APT Framework: Univ., Wirtschaftswiss. Fak.

Arellano-Bond Linear Dynamic Panel-Data Estimation. (2015). from http://www.stata.com/manuals 13/xtxtabond.pdf accessed on 06.11.2015

Arellano, M. (2003). Panel Data Econometrics: OUP Catalogue.

Arellano, M., \& Bond, S. (1991). Some Tests of Specification for Panel Data: Monte Carlo Evidence and an Application to Employment Equations. The review of economic studies, 58(2), 277-297. https://doi.org/10.2307/2297968

Aydeniz, E. (2009). Makroekonomik Göstergelerin Firmaların Finansal Performans Ölçütleri Üzerindeki Etkisinin Ölçülmesine Yönelik Bir Araştırma: IMKB'ye Kote Gıda ve İçecek İşletmeleri Üzerine bir Uygulama. Marmara Üniversitesi IIIBF Dergisi, 27.

Bailey, W., \& Chung, Y. P. (1995). Exchange Mate Fluctuations, Political Risk, and Stock Returns: Some Evidence from an Emerging Earket. Journal of Financial and Quantitative Analysis, 30(04), 541-561. https://doi.org/10.2307/2331276

Bartov, E., \& Bodnar, G. M. (1994). Firm Valuation, Earnings Expectations, and the Exchange-Rate Exposure Effect. Journal of finance, 1755-1785. https://doi.org/10.1111/j.1540-6261.1994.tb04780.x

Bartov, E., Bodnar, G. M., \& Kaul, A. (1995). Exchange Rate Variability and the Riskiness of US Multinational Firms: Evidence from the Breakdown of the Bretton Woods System. NBER Working Paper(w5323).

Baum, C. F., Caglayan, M., \& Barkoulas, J. T. (2001). Exchange Rate Uncertainty and Firm Profitability. Journal of Macroeconomics, 23(4), 565-576. https://doi.org/10.1016/S0164-0704(01)00178-1

Bernanke, B. S., \& Kuttner, K. N. (2005). What Explains the Stock Market's Reaction to Federal Reserve Policy? The Journal of Finance, 60(3), 1221-1257. https://doi.org/10.1111/j.1540-6261.2005.00760.x

Buyuksalvarci, A. (2010). The Effects of Macroeconomics Variables on Stock Returns: Evidence from Turkey. European Journal of Social Sciences, 14(3), 404-416.

Caloghirou, Y., Protogerou, A., Spanos, Y., \& Papagiannakis, L. (2004). Industry-Versus Firm-Specific Effects on Performance:: Contrasting SMEs and Large-Sized Firms. European Management Journal, 22(2), 231-243. https://doi.org/10.1016/j.emj.2004.01.017

Canarella, G., Miller, S. M., \& Nourayi, M. M. (2013). Firm Profitability: Mean-Reverting or Random-Walk Behavior? Journal of Economics and Business, 66, 76-97. https://doi.org/10.1016/j.jeconbus.2012.11.002

Chan, L. K., Karceski, J., \& Lakonishok, J. (1998). The Risk and Return from Factors. Journal of Financial and Quantitative Analysis, 33(02), 159-188. https://doi.org/10.2307/2331306

Dumas, B. (1978). The Theory of the Trading Firm Revisited. The Journal of Finance, 33(3), 1019-1030. https://doi.org/10.1111/j.1540-6261.1978.tb02041.x

Durukan, M. B. (1999). İstanbul Menkul Kıymetler Borsası'nda Makroekonomik Değişkenlerin Hisse Senedi Fiyatlarına Etkisi. IMKB Dergisi, 3(11), 19-47.

Eurostat, N. (2008). Rev. 2-Statistical Classification of Economic Activities in the European Community. Office for Official Publications of the European Communities, Luxemburg.

Flannery, M. J., \& Protopapadakis, A. A. (2002). Macroeconomic Factors do Influence Aggregate Stock Returns. Review of Financial Studies, 15(3), 751-782. https://doi.org/10.1093/rfs/15.3.751

Gao, T. (2000). Exchange Rate Movements and the Profitability of US Multinationals. Journal of International Money and Finance, 19(1), 117-134. https://doi.org/10.1016/S0261-5606(99)00038-8

Goldszmidt, R. G. B., Brito, L. A. L., \& de Vasconcelos, F. C. (2011). Country Effect on Firm Performance: A Multilevel Approach. Journal of Business Research, 64(3), 273-279. 
https://doi.org/10.1016/j.jbusres.2009.11.012

Guerrini, A., Romano, G., \& Campedelli, B. (2011). Factors Affecting the Performance of Water Utility Companies. International Journal of Public Sector Management, 24(6), 543-566. https://doi.org/10.1108/09513551111163657

Hussainey, K., \& Khanh Ngoc, L. (2009). The Impact of Macroeconomic Indicators on Vietnamese Stock Prices. The Journal of Risk Finance, 10(4), 321-332. https://doi.org/10.1108/15265940910980632

Jorion, P. (1990). The Exchange-Rate Exposure of US Multinationals. Journal of business, 331-345. https://doi.org/10.1086/296510

Karabag, S. F., \& Berggren, C. (2014). Antecedents of Firm Performance in Emerging Economies: Business Groups, Strategy, Industry Structure, and State Support. Journal of Business Research, 67(10), 2212-2223. https://doi.org/10.1016/j.jbusres.2014.01.004

Karamustafa, O., \& Karakaya, A. (2004). Enflasyonun Borsa Performansı Üzerindeki Etkisi. Kocaeli Üniversitesi Sosyal Bilimler Enstitüsü Dergisi, 7(1), 23-35.

Ketelhöhn, N. W., \& Quintanilla, C. (2012). Country Effects on Profitability: A Multilevel Approach Using a Sample of Central American Firms. Journal of Business Research, 65(12), 1767-1772. https://doi.org/10.1016/j.jbusres.2011.10.036

Kyereboah-Coleman, A., \& Agyire-Tettey, K. F. (2008). Impact of PMacroeconomic Indicators on Stock Market performance: The case of the Ghana Stock Exchange. The Journal of Risk Finance, 9(4), 365-378. https://doi.org/10.1108/15265940810895025

Naceur, S. B. (2003). The Determinants of the Tunisian Banking Industry Profitability: Panel Evidence. Universite Libre de Tunis working papers.

Oskenbayev, Y., Yilmaz, M., \& Chagirov, D. (2011). The Impact of Macroeconomic Indicators on Stock Exchange Performance in Kazakhstan. African Journal of Business Management, 5(7), 2985-2991.

Pasiouras, F., \& Kosmidou, K. (2007). Factors Influencing the Profitability of Domestic and Foreign Commercial Banks in the European Union. Research in International Business and Finance, 21(2), 222-237. https://doi.org/10.1016/j.ribaf.2006.03.007

Pilinkus, D. (2010). Macroeconomic Indicators and Their Impact on Stock Market Performance in the Short and Long Run: The Case of the Baltic States. Technological and Economic Development of Economy(2), 291-304. https://doi.org/10.3846/tede.2010.19

Shapiro, A. C. (1975). Exchange Rate Changes, Inflation, and the Value of the Multinational Corporation. The Journal of Finance, 30(2), 485-502. https://doi.org/10.1111/j.1540-6261.1975.tb01824.x

Sharpe, S. A. (1999). Stock Prices, Expected Returns, and Inflation. FEDS Working Paper(99-2). https://doi.org/10.2139/ssrn.155071

The Top 500 Largest Industrial Organizations of Turkey 2014. (2015). Istanbul Chamber of Industry.

United Nations Statistics Division. (2015). from https://unstats.un.org/unsd/cr/registry/regcst.asp?Cl=8 accessed on $10 / 12 / 2015$

Wickremasinghe, G. (2011). The Sri Lankan Stock Market and the Macroeconomy: An Empirical Investigation. Studies in Economics and Finance, 28(3), 179-195. https://doi.org/10.1108/10867371111141954

Yazdanfar, D. (2013). Profitability Determinants Among Micro Firms: Evidence from Swedish Data. International Journal of Managerial Finance, 9(2), 151-160. https://doi.org/10.1108/17439131311307565

Yurtoglu, B. B. (2004). Persistence of Firm-Level Profitability in Turkey. Applied Economics, 36(6), 615-625. https://doi.org/10.1080/0003684042000217652 
Appendix 1. Sectoral Classification According to ISIC Rev. 2

\begin{tabular}{lc}
\hline Sectors & Sectors Code \\
\hline Food Manufacturing & 311 \\
Food Manufacturing Not Elsewhere Classified & 312 \\
Beverage industries & 313 \\
Tobacco Processing & 314 \\
Manufacture of Textiles & 321 \\
Manufacture of Wearing Apparel, except footwear & 322 \\
Manufacture of Wood and Products of Wood and cork & 331 \\
Manufacture of Wooden Furniture & 332 \\
Manufacture of Paper and Paper Products & 341 \\
Printing and Publishing & 342 \\
Manufacture of Basic Chemicals & 351 \\
Manufacture of other Chemical Products & 352 \\
Manufacture of Petroleum Products & 353 \\
Oil and Coal Derivatives & 354 \\
Manufacture of Rubber goods & 355 \\
Manufacture of Plastics Products NEC & 356 \\
Manufacture of Pottery, china, earthenware and porcelain & 361 \\
Manufacture of Glass and Glass Products & 362 \\
Manufacture of Other nonmetalic mineral Products & 369 \\
Manufacture of Basic Iron and Steel & 371 \\
Manufacture of non-ferrous metals & 372 \\
Manufacture of Metal Products & 381 \\
Manufacture of Machinery except electirical & 382 \\
Manufacture of electirical Machinery Apparatus and appliances & 383 \\
Manufacture of motor Vehicles & 384 \\
Other Manufacturing & 390 \\
\hline
\end{tabular}

\section{Copyrights}

Copyright for this article is retained by the author(s), with first publication rights granted to the journal.

This is an open-access article distributed under the terms and conditions of the Creative Commons Attribution license (http://creativecommons.org/licenses/by/4.0/). 